\title{
An annotated list of type specimens of Orthoptera (Insecta) described by Ferdinand Karsch and deposited in the collections of the Muséum d'histoire naturelle de la Ville de Genève
}

\author{
John HOLLIER \\ Muséum d'histoire naturelle, C.P. 6434, CH-1211 Genève 6, Switzerland. \\ Email: John.Hollier@ville-ge.ch.
}

\begin{abstract}
An annotated list of type specimens of Orthoptera (Insecta) described by Ferdinand Karsch and deposited in the collections of the Muséum d'histoire naturelle de la Ville de Genève. - Probable type specimens of twenty two species of Orthoptera described by Karsch have been identified in the collection of the Museum. The names are listed alphabetically together with the number, sex and label data of the specimens, their location in the collection, and the current nomenclatural combination.
\end{abstract}

Keywords: Orthoptera - type material - Karsch.

\section{INTRODUCTION}

Ferdinand Karsch (1853-1936) was an important entomologist, arachnologist and anthropologist who worked as curator at the Museum für Naturkunde in Berlin from 1878 to 1921 . He produced some thirty publications dealing with Orthoptera, most of them relating to the German colonies in Africa. Karsch often indicated how many specimens he had, though it is not always stated, but did not designate a type specimen where he had more than one, so that these series are syntypes. The bulk of the material he studied is in Berlin (Groll, 2006).

The Orthoptera collections of the Muséum d'histoire naturelle de la Ville de Genève (MHNG) contain a large number of specimens, mainly African, from the Museum für Naturkunde in Berlin. It is not clear how or when this material came to the MHNG; it must have arrived after 1896, when some of the species were described. It seems probable that it relates to the expedition by Johann Carl of the MHNG to eastern central Africa (including some German colonies) in 1908.

The Berlin specimens are easily identified by the characteristic printed blue data labels, the usual MHNG labels for African specimens being red or pink, and often handwritten. Amongst this material are some 40 species described by Karsch, some of which have been labelled as "types" or "co-types" by someone at the MHNG. Some of these examples cannot be types in the modern sense, because the description mentions only one specimen (and a holotype is in Berlin), or the locality data are different (and sometimes collected after the description was published). Others are almost certainly syntypes, and are listed below, though it remains possible that some of these specimens are subsequent captures at the type locality. 


\section{ARRANGEMENT AND FORMAT}

The species are listed alphabetically. The format for each is:

species Author, work: page [Original generic placement].

Number of specimens: "Label data" [format of label].

Comments and location of material in MHNG collections.

Currently valid binomen of taxon, based on OSF.

The abbreviation OSF refers to Orthoptera Species File Online (Eades \& Otte, 2009).

agomena Karsch, 1896: 282. [Caryanda].

One $q$ with labels: "Togo, Misahöhe 1893, E. Baumann S." [printed on blue card]; "Caryanda agomena Karsch, type" [handwritten on pink paper].

Box Z18.

Carydana agomena (Karsch, 1896).

asymmetrica Karsch, 1896: 330 [Pardalota].

One $\delta$ and one $q$ with labels: "Ussagau - Uganda, Mai-Aug. 1894, O. Neumann S." [handwritten on blue card]; "Pardalota asymmetrica Karsch (ex Mus. Berlin)" [handwritten on pink paper].

Box B9.

Pardalota asymmetrica Karsch, 1896.

denudatus Karsch, 1891b: 330 [Apteroscirtus].

One ơ with labels: "Kamerun, Barombi-Stat., Preuss S." [printed on blue card]; "Apteroscirtus denudatus Karsch" [handwritten on pink paper]; "co-type" [printed on pink card].

Box D5.

Apteroscirtus denudatus Karsch, 1891.

doenitzi Karsch, 1889: 461 [Cosmozoma].

One ô with labels: "Madagascar, H. de Saussure" [printed on white paper]; "Cosmozoma doenitzi Karsch" [handwritten on pink paper]; "P. Naskrecki Note: possibly a type, July 2002" [handwritten on white paper].

There are several other specimens with the same data labels in the insect box, the identification of this specimen as a type is therefore doubtful. Box B21.

Cosmozoma doenitzi Karsch, 1889.

festa Karsch, 1893: 74 [Zacompsa].

One $q$ with labels: "Togo, Bismarckburg, 15-31.12.90 R. Büttner S." [printed on blue card]; "Zacompsa festa Karsch, type" [handwritten on pink paper].

According to OSF the lectotype of this species is in Berlin, making this specimen a paralectotype. Box U16.

Zacompsa festa Karsch, 1893.

festivus Karsch, 1891a: 190 [Stenocrobylus].

One $\delta$ and one $q$ with labels: "Kamerun, Barombi-Stat., Preuss S." [printed on blue card]; "Stenocrobylus festivus Karsch type" [handwritten on pink paper]. 
Box Z55.

Stenocrobylus festivus Karsch, 1891.

fullonius Karsch, 1896: 251 [Odontomelus].

One $q$ with labels: "Chinchoxo, Falkenstein S." [printed on blue card]; "Odontomelus fullonius Karsch, type" [handwritten on pink paper].

According to OSF the holotype of this species is in Berlin, but the likelihood of specimens with the same collector and locality data not being syntypes seems low (only the female sex mentioned in description). Box U9.

Phryganimelus fullonius (Karsch, 1896).

granulosus Karsch, 1886: 316 [Mecopoda].

One $q$ with labels: "Kamerun, Gebirge Buea, Preuss S." [printed on blue card]; "Leproscirtus granulosus Karsch" [handwritten on pink paper].

Box D5.

Leproscirtus granulosus (Karsch, 1886).

inclusa Karsch, 1893: 125 [Pachypyga].

One $q$ with labels: "Togo, Bismarckburg, 15-31.12.90 R. Büttner S." [printed on blue card]; "Pachypyga inclusa Karsch, cotype" [handwritten on pink paper].

Box B5.

Horatosphaga inclusa (Karsch, 1893).

lauta Karsch, 1896: 282 [Badistica].

One + with labels: "Togo, Misahöhe 1893, E. Baumann S." [printed on blue card]; "Badistica lauta Karsch, type" [handwritten on pink paper].

Box Z18.

Badistica lauta Karsch, 1896.

luculenta Karsch, 1896: 254 [Paracinema].

One ơ with labels: "Togo, Misahöhe 94, E Baumann S." [printed on blue card]; "Paracinema luculenta Karsch, type" [handwritten on pink paper].

Box U15.

Paracinema luculenta Karsch, 1896.

miniatulus Karsch, 1893: 108 [Pterotiltus].

One đo with labels: "Bismarckburg, Togoland 91, R Büttner S." [printed on blue card]; "Pterotiltus miniatulus Karsch, type" [handwritten on pink paper].

Box Z15.

Pterotiltus miniatulus Karsch, 1893.

munda Karsch, 1893: 70 [Rhabdoplea].

One $\delta$ with labels: "Bismarckburg, Togoland, R Büttner S." [printed on blue card]; "Rhabdoplea munda Karsch, type" [handwritten on pink paper].

Box U16.

Rhabdoplea munda Karsch, 1893. 
nitidula Karsch, 1891a: 185 [Segellia].

Three $\delta \delta$ and two $q f$ with labels: "Kamerun, Barombi-Stat., Preuss S." [printed on blue card]; "Segellia nitidula Karsch, type" [handwritten on pink paper].

Box Z51.

Segellia nitidula Karsch, 1891.

nyassicus Karsch, 1896: 313 [Orbillus].

Two $\delta \hat{\delta}$ and two $q$ q with labels: "Nyassaland, Milanji, Brown V" [printed on blue card]; "Orbillus nyassicus Karsch, type" [handwritten on pink paper].

Box Z54.

A junior synonym of Eupropacris cylindricollis (Schaum, 1853).

parcispinosa Karsch, 1893: 140 [Clasma].

One $q$ with labels: "Bismarckburg, Togoland, R Büttner S." [printed on blue card]; "Clasma parcispinosa Karsch, (ex Mus. Berlin)" [handwritten on pink paper].

Box F4.

Clasma parcispinosa Karsch, 1893.

pellucida Karsch, 1888b: 161 [Amytta].

One + with labels: "Usambara, CW Schmidt Feb-März 86" [printed on blue card]; "Amytta pellucida Karsch" [handwritten on pink paper].

Box C1.

Amytta pellucida Karsch, 1888.

putidus Karsch, 1896: 315 [Catantops].

Three $\delta \hat{\delta}$ and three $q+$ with labels: "Nyassaland, Milanji, Brown V" [printed on blue card]; "Catantops putidus Karsch, type" [handwritten on pink paper].

Box Z52.

Cardeniopsis putidus (Karsch, 1896).

rectiloba Karsch, 1890: 355 [Dithela].

One $\delta$ and one $q$ with labels: "Kamerun, Barombi-Stat.,

Preuss S." [printed on blue card]; "Dithela rectiloba Karsch, type" [handwritten on pink paper].

Box B8.

Dithela rectiloba Karsch, 1890.

saturata Karsch, 1892: 74 [Gravenreuthia].

One $q$ with labels: "Kamerun, Gebirge Buea, Preuss S." [printed on blue card]; "Gravenreuthia saturata Karsch (ex Mus. Berlin)" [handwritten on pink paper].

Box B15.

Gravenreuthia saturata Karsch, 1892.

tenuipes Karsch, 1890: 363 [Poreumena].

One $q$ with labels: "Kamerun, Barombi-Stat., Preuss S." [printed on blue card]; "Cestromoecha tenuipes Karsch" [handwritten on pink paper]. 
Box B15.

Cestromoecha tenuipes (Karsch, 1890).

unguiculatus Karsch, 1888a: 147 [Mecopoda].

One $q$ with label: "Gymnoscirtus unguiculatus Karsch" [handwritten on pink paper]; "co-type" [printed on pink card]. The label in the insect box has the locality "Usumbura" hand written in the bottom left corner (something often encountered in the MHNG collection). OSF states that the holotype of this species is in Berlin, but this is obviously an error because the original description details both male and female characters, without designating a holotype. Box D8.

Mecopoda unguiculatus Karsch, 1888.

There is also a specimen of Orthacanthacris humilicrus (Karsch, 1896) in box Z37 that has lost any labels once present, and which could be a syntype.

\section{DISCUSSION}

The presence of syntypes of Karsch species in the MHNG collection is unexpected. Primary types of all these species are present in the Museum für Naturkunde in Berlin, but the discovery of additional type material serves to further highlight the importance of the MHNG collections.

\section{ACKNOWLEDGEMENTS}

Thanks are due to Peter Schwendinger and Anita Hollier for comments on the layout and text, and to Bernd Hauser for historical information about the collections.

\section{REFERENCES}

Eades, D. C. \& OtTe, D. 2009. Orthoptera Species File Online. Version 2.0/3.5. at $<$ http://Orthoptera.SpeciesFile.org > [Accessed 23.ix.2009].

GROLL, E. K. (ed.) 2006. Entomologists of the world (biographies, notes on the current locations of entomological collections). Database 2. version, DEI im ZALF e.V.

KARSCH, F. 1886. Eine neue westafrikanische Mecopode. Entomologische Nachrichten Berlin 12: 316-318.

KARSCH, F. 1888a. Zwei neue Mecopoda-Arten (Orthoptera). Entomologische Nachrichten Berlin 14: 145-148.

KARSCH, F. 1888b. Die Meconemiden. Ein orthopterologischer Beitrag. Wiener Entomologische Zeitung 7: 159-162.

KARSCH, F. 1889. Orthopterologische Beiträge III. Berliner Entomologische Zeitschrift 32: 415-464.

KARSCH, F. 1890. Verzeichnis der von Herrn Dr. Paul Preuss auf der Barombi-Station in Deutsch-Westafrika 1890 gesamellen Locustodeen aus den Familien der Phaneropteriden, Meconemiden und Gryllacriden. Entomologische Nachrichten Berlin 16: 353-369.

Karsch, F. 1891a. Verzeichnis der von Herrn Dr. Paul Preuss in Kamerun erbeuteten Acridiodeen. Berliner Entomologische Zeitschrift 36:175-196.

KARSCH, F. 1891b. Übersicht der von Dr. Paul Preuss auf der Barombi-Station in Kamerun gesammelten Locustodeen. Berliner Entomologische Zeitschrift 36(2):317-446. 
KarsCh, F. 1892. Verzeichnis der von Herrn Dr. Paul Preuss im Kamerungebirge erbeuteten Orthopteren. Berliner Entomologische Zeitschrift 37: 65-78.

KARSCH, F. 1893. Die Insekten der Berglandschaft Adeli im Hinterlande von Togo (Westafrika), I. Berliner Entomologische Zeitschrift 38: 1-266, 6 pls.

Karsch, F. 1896. Neue Orthopteren aus dem tropischen Afrika. Stettiner Entomologische Zeitung 57: 242-359. 


\section{$2 \mathrm{BHL}$ Biodiversity Heritage Library}

Hollier, John. 2010. "An annotated list of type specimens of Orthoptera (Insecta) described by Ferdinand Karsch and deposited in the collections of the Muséum d'histoire naturelle de la Ville de Genève." Revue suisse de zoologie 117, 17-22. https://doi.org/10.5962/bhl.part.117585.

View This Item Online: https://www.biodiversitylibrary.org/item/148549

DOI: https://doi.org/10.5962/bhl.part.117585

Permalink: https://www.biodiversitylibrary.org/partpdf/117585

\section{Holding Institution}

American Museum of Natural History Library

\section{Sponsored by}

BHL-SIL-FEDLINK

\section{Copyright \& Reuse}

Copyright Status: In copyright. Digitized with the permission of the rights holder.

Rights Holder: Muséum d'histoire naturelle - Ville de Genève

This document was created from content at the Biodiversity Heritage Library, the world's largest open access digital library for biodiversity literature and archives. Visit BHL at https://www.biodiversitylibrary.org. 